\title{
Genetic diversity of a Paspalum notatum Flügge germplasm collection
}

\author{
Juliana Maria Fachinetto', Miguel Dall'Agnol ${ }^{2}$, Cleber Henrique Lopes de Souza ${ }^{3}$, Roberto Luis \\ Weiler $^{2}$, Carine Simioni ${ }^{2}$
}

\footnotetext{
1 Universidade Regional do Noroeste do Estado do Rio Grande do Sul, ljuí, RS, Brazil.

${ }^{2}$ Universidade Federal do Rio Grande do Sul, Faculdade de Agronomia, Departamento de Plantas Forrageiras e Agrometeorologia, Porto Alegre, RS, Brazil.

${ }^{3}$ Universidade Federal do Rio Grande do Sul, Programa de Pós-graduação em Zootecnia, Porto Alegre, RS, Brazil.
}

\begin{abstract}
The objective of this study was to assess the genetic diversity among accessions of Paspalum notatum based on morphological marker traits and identify those morphological traits that contribute most to the variability among accessions. Fifty-three accessions were evaluated for the following traits: length, width, color, and pubescence of sheath; length, width, insertion angle, color of midrib, and pubescence of leaves; number, length, and angle of racemes; length of flowering stems; and plant growth habit (erect or prostrate). Multivariate analysis of the quantitative morphological data based on the Mahalanobis distance and UPGMA method grouped the accessions into 19 heterogeneous clusters. The relative contribution of each trait to cluster formation was obtained using the Singh method. Qualitative morphological traits were used to construct a dendrogram based on Jaccard's similarity, generating 13 clusters. Based on the morphological traits investigated, there is high genetic variation among accessions of $P$. notatum, demonstrating that these accessions have a good potential for a breeding program. Length of racemes, width of sheath, length of flowering stems, and length of leaves were found to contribute most to the variability among accessions. A number of traits contributed to a lesser degree. The set of characters used are representative of the vast phenotypic plasticity observed in P. notatum, a diversity which is likely to be related to the species apomictic form of reproduction and the origin of the accessions.
\end{abstract}

Key Words: forage grass, genetic improvement, multivariate analysis

\section{Introduction}

Species of the genus Paspalum L. are the main components of native pasture in the tropical and subtropical regions of the Americas (Sartor et al., 2009). Most species of Paspalum are apomictic tetraploids or sexual self-incompatible diploids (Ortiz et al., 2013). From an evolutionary point of view, the genus Paspalum, therefore, represents an excellent model for the investigation of the role of apomixis and polyploidy (Whitton et al., 2008; Ortiz et al., 2013). From an agronomic point of view, the reproductive mode of the species of the genus Paspalum is of relevance, since the development of new cultivars relies on natural genetic variation, and intra- and interspecific hybridization efforts are affected by the reproductive mode

Received: December 15, 2016

Accepted: July 7, 2017

*Corresponding author: migueld@ufrgs.br

http://dx.doi.org/10.1590/S1806-92902017000900002

How to cite: Fachinetto, J. M.; Dall'Agnol, M.; Souza, C. H. L.; Weiler, R. L. and Simioni, C. 2017. Genetic diversity of a Paspalum notatum Flügge germplasm collection. Revista Brasileira de Zootecnia 46(9):714-721.

Copyright (C) 2017 Sociedade Brasileira de Zootecnia. This is an Open Access article distributed under the terms of the Creative Commons Attribution License (http://creativecommons.org/licenses/by/4.0/), which permits unrestricted use, distribution, and reproduction in any medium, provided the original work is properly cited.
(Adamowski et al., 2005). Among the forage grasses of the genus Paspalum, Paspalum notatum Flügge is of great importance because of its wide distribution in the natural grasslands of the Pampa region (Boldrini et al., 2010). Favored by its growth habit, the species distribution is gradually further increasing and is considered one of the most promising native forage grasses in its region (Barreto, 1974; Canto-Dorow et al., 1996; Pozzobon and Valls, 1997). The genetic and morphological diversity of the species holds great potential for the development of new cultivars with desirable characteristics (Canto-Dorow et al., 1996; Pozzobon and Valls, 1997; Steiner, 2005; Cidade et al., 2008; Dahmer et al., 2008).

Studies of morphological variation in plants are a useful tool in genetic improvement programs and enable access to the genetic variability within a germplasm bank (Azevedo et al. 2011; Martuscello et al., 2012). In plant breeding programs, knowledge of variability and genetic diversity within a species is essential for the rational use of genetic resources (Govindaraj et al., 2015).

The development of new cultivars in Paspalum has been focused on identifying genotypes with high forage production, using sexual parents to generate genetic variability. In addition, these materials have been characterized in relation to their genetics and morphology 
(Dahmer et al., 2008; Fachinetto et al., 2012; Pereira et al., 2012; Pereira et al. 2015). Subsequently, these materials are subjected to intra or interspecific crosses, using duplicate diploid sex plants as the female parent (Huber et al., 2016; Machado et al., 2017).

In face of the great productive potential of $P$. notatum evidenced by previous studies (Fachinetto el al., 2012), the objectives of this study were to assess the genetic variability among accessions of $P$. notatum based on morphological traits, study the genetic diversity based on morphological traits, and identify the traits that contributed most to the discrimination of accessions.

\section{Material and Methods}

The seeds of 25 accessions of $P$. notatum were obtained from the United States Department of Agriculture (USDA). They had been collected at different locations in southern Brazil, Argentina, Uruguay, and Paraguay during the 1950s and 1970s (Figure 1) (Fachinetto et al., 2012). Twenty-seven accessions were obtained from the Departamento de Plantas Forrageiras e Agrometeorologia (DPFA) of the Faculdade de Agronomia, Universidade Federal do Rio Grande do Sul (UFRGS) and cloned vegetatively. These had been collected at different locations in Rio Grande do Sul and São Paulo (Brasil), Uruguay, and Argentina (Figure 1) (Dahmer et al., 2008). Clones of the cultivar Pensacola and two biotypes of Paspalum guenoarum were used as control. In total, 55 accessions were included in the experiment in the form of seedlings, which were established in the spring of 2008. The experimental design was completely randomized with five replicates, using 10 lines with 28 plants in each, totalizing 280 plants. Plants were spaced at $1-\mathrm{m}$ intervals and evaluated individually. Before the installation of the

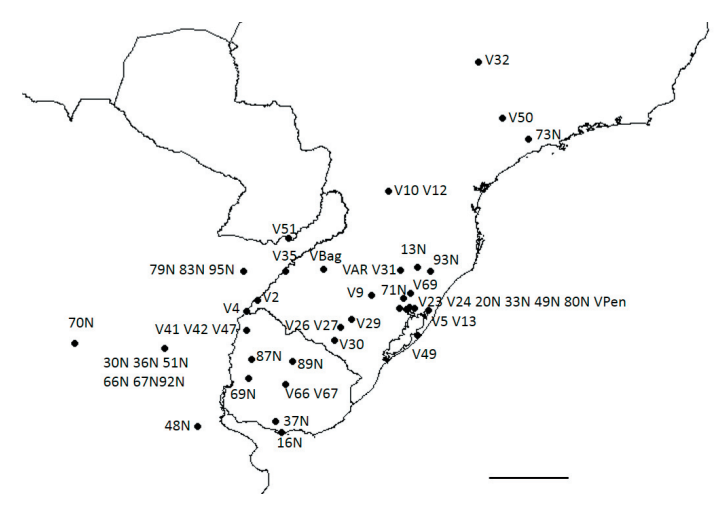

Scale: $300 \mathrm{~km}$.

Figure 1 - Location of Paspalum notatum accessions. experiment, a basic fertilization was carried out according to recommendations and to the soil analysis. Subsequently, fertilizations were performed in three fractional doses of nitrogen. The experiment was irrigated by aspersion to avoid water deficit in the evaluation period.

The experimental area is located in the physiographic region of the Central Depression, whose climate is of the Cfa type, subtropical humid with hot summer, according to the Köppen classification. Average monthly temperatures range from 9 to $25^{\circ} \mathrm{C}$, with January and February as the hottest months, and June and July as the coldest months. The annual average precipitation is $1466 \mathrm{~mm}$, while the monthly average is $125 \mathrm{~mm}$. The soil is classified as Dystrophic Red Argisol - Pvd (Streck et al., 2002).

Morphological analyses were performed at full flowering during the summer of 2009. All measurements were taken in three replicates for all 53 accessions of $P$. notatum, except for $P$. guenoarum. The following characteristics were evaluated for each accession: length of sheath (LS; $\mathrm{cm}$ ), width of sheath (WS; $\mathrm{cm}$ ), color of sheath (CS; visual scores: 1- greenish, 2- violaceus), pubescence of sheath (PS; visual scores: 1- pubescent, 2- glabrous); length of leaves (LL; cm), width of leaves (WL; cm), insertion angle of leaves (IAL; grade), color of midrib of leaves (CML; visual score: 1- white; 2- greenish), pubescence of leaves (PL; visual scores: 1- pubescent, 2glabrous); number of racemes (RN), length of raceme $(\mathrm{LR} ; \mathrm{cm})$, angle between racemes (AR; grade), length of flowering stems (LFS; cm), and plant habit (PH; visual scores: 1- erect; 2- prostrate). To facilitate a standardized comparison between accessions, the measurements of sheaths and leaf blades were performed on the first leaf below the flag leaf. In the inflorescences with more than two racemes, the angulation was measured among the external racemes.

A multivariate analysis of all quantitative data was performed. In the clustering analysis, the Mahalanobis generalized distance $\left(\mathrm{D}^{2}\right)$ was used to measure dissimilarity and constructed an Unweighted Pair Group (UPGMA) dendrogram. The relative importance of the characters was determined from the non-standard average using the Singh method (Singh, 1981). Statistical analyses were carried out using the GENES software (Cruz, 2006).

Quantitative data obtained were transformed into binary matrix. To estimate the similarity among the accessions, Jaccard's coefficient was used, through the similarity of qualitative data (SIMQUAL), and clustering analysis constructed the UPGMA dendrogram using NTSYS 2.1 (Rohlf, 1998). 
Results

Mean leaf sheath lengths and widths ranged within and among accessions. In certain accessions, only a single leaf sheath color (violaceous or green) was found. In others, the color of the leaf sheath showed variation. Leaf sheaths were glabrous in all accessions, with the exception of accessions V49 (completely pubescent) and V50 (variable) (Table 1).

All the characters measured in leaf blade were variables among accessions. The midrib color of leaves ranged from

Table 1 - Morphologic characteristics of the of Paspalum notatum accessions

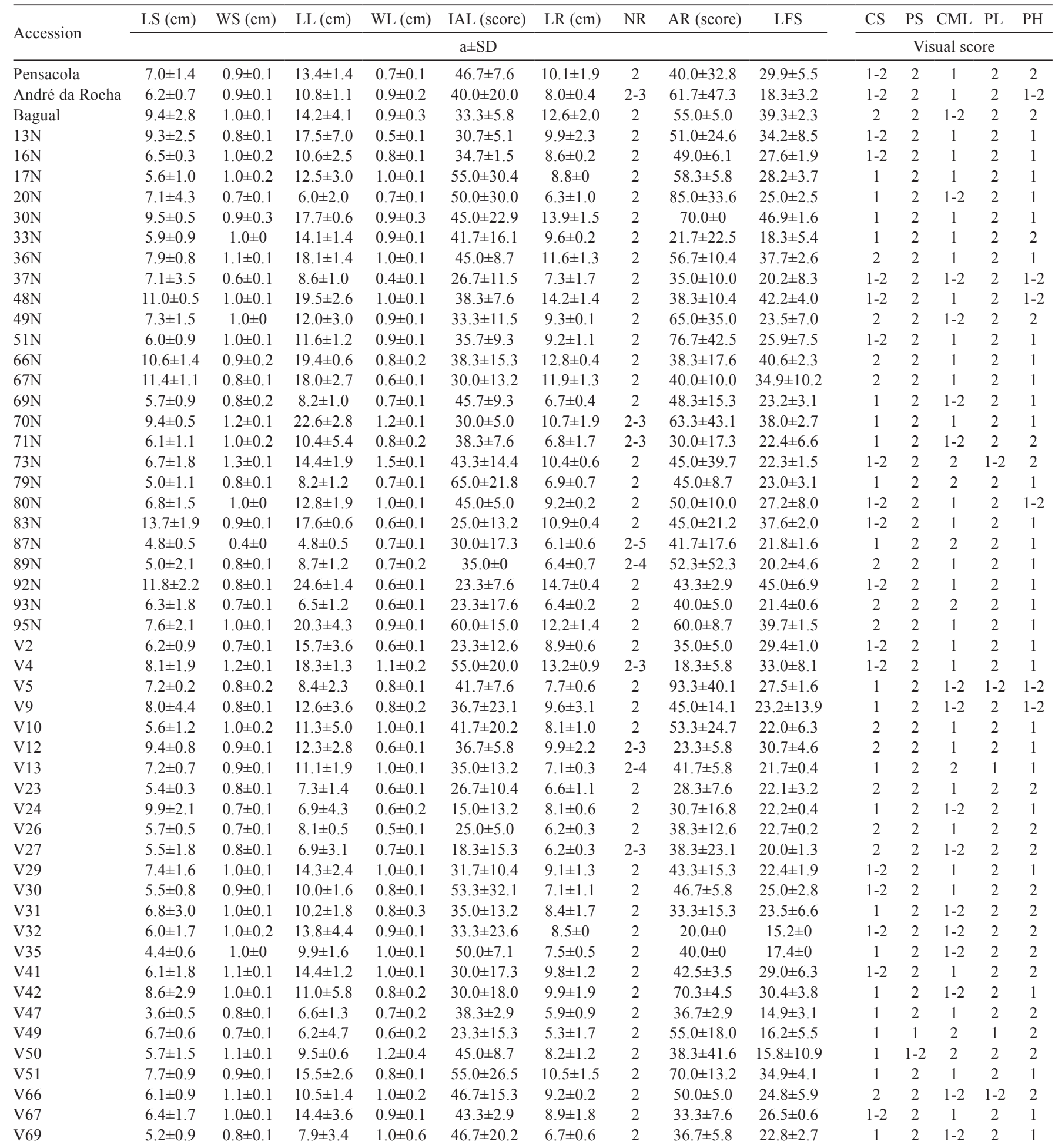

a - average; SD - standard deviation; LS - length of sheath; WS - width of sheath; LL - length of leaves; WL - width of leaves; IAL - insertion angle of leaves; LR - length of racemes; NR - number of racemes; AR - angle between the racemes; LFS - length of flowering stems; CS - color of sheath (1- greenish, 2- violaceus); PS - pubescence of sheath (1- pubescent, 2- glabrous); CML - color of midrib of leaves (1- white, 2- greenish); PL - pubescence of leaves (1- pubescent, 2- glabrous); PH - plant habit (1- erect, 2-prostrate). 
full white to full green, with variation in some accessions. In most accessions, the leaf blades were glabrous, two accessions (V13 and V49) had pubescent leaves only, and there was variation in three accessions (Table 1).

In most accessions, the inflorescence consisted of two racemes, although three, four, and up to five racemes were observed in some accessions (V13,70N, 87N, and 89N). Length of raceme, angle between racemes, and length of the flowering stems also ranged within and among accessions (Table 1).

Twenty-nine accessions had an erect habit, 18 had a prostrate habit, and six showed variation (Table 1).

The highest variance among the evaluated characteristics was seen for the angle between racemes $\left(\right.$ AR $\left.s^{2}=244.48\right)$, with maximum and minimum mean values of 93.33 and $18.33^{\circ}$, respectively (Table 2). This trait accounted for $53.65 \%$ of the total variance observed. The insertion angle of the leaves (IAL $\mathrm{s}^{2}=116.94$ ), which ranged from 65.0 to $15.0^{\circ}$, contributed $25.65 \%$ to the total variance. The length of flowering stems (LFS $s^{2}=63.60$ ) presented values between 46.9 and $14.9 \mathrm{~cm}$ and contributed $14 \%$ of the total variance. These three characteristics alone accounted for $93.26 \%$ of the total variance of the nine traits evaluated in the present study.

The clustering analysis using UPGMA method based on the Mahalanobis distance divided the studied accessions into 19 groups (Figure 2). In all groups, there was a wide variation in the characteristics studied. The greatest difference was observed between accessions $87 \mathrm{~N}$ and $70 \mathrm{~N}$ (109.89). The smallest difference was observed between accessions V26 and 93N (0.99).

It is important to consider the contribution of each of the assessed traits to the variability among accessions (Table 3). Here, the traits that contributed the most were length of racemes $(21.59 \%)$, width of sheath $(20.09 \%)$, length of flowering stems $(18.70 \%)$, and length of leaves (16.61\%). Together, these traits accounted for $76.99 \%$ of

Table 2 - Descriptive statistics of the quantitative morphological characteristics

\begin{tabular}{lcccc}
\hline Variable & Variance & Average & Maximum & Minimum \\
\hline LS & 4.15 & 7.19 & 13.7 & 3.6 \\
WS & 0.03 & 0.91 & 1.27 & 0.4 \\
LL & 21.06 & 12.37 & 24.6 & 4.8 \\
WL & 0.03 & 0.83 & 1.47 & 0.4 \\
IAL & 116.94 & 37.83 & 65.0 & 15.0 \\
LR & 5.42 & 9.02 & 14.68 & 5.28 \\
NR & 0.02 & 2.06 & 3.0 & 2.0 \\
AR & 244.48 & 47.15 & 93.33 & 18.33 \\
LFS & 63.60 & 26.95 & 46.9 & 14.9 \\
\hline
\end{tabular}

LS - length of sheath; WS - width of sheath; LL - length of leaves; WL - width of leaves; IAL - insertion angle of leaves; LR - length of racemes; NR - number of racemes; AR - angle between the racemes; LFS - length of flowering stems. the variability among accessions. Jaccard's similarity index obtained to qualitative morphological characters was 0.88 and formed 13 groups (Figure 3). Seven groups were formed by a single accession, while the others grouped accessions with Jaccard's similarity equal to 1 .

\section{Discussion}

Morphological characterization, one of the most traditional forms of germplasm characterization, helps to describe the genetic diversity existing within a plant species. The outcomes of the morphological analysis can then be linked to environmental conditions and to the results of cytological, agronomic, and genetic analyses (Borner et al., 2006). Multivariate analysis techniques can be used to evaluate the differences among accessions and to select the descriptors that best allow to discriminate among the accessions in a germplasm bank (Azevedo et al., 2011; Santos et al., 2011).

Previous work on the morphological characterization of $P$. notatum has shown the polymorphic nature of this species and a subdivision of the species into varieties has been suggested (Parodi, 1948; Rosengurt et al., 1970). However, others maintain that there are only two true varieties, $P$. notatum var. saurae (a diploid sexual) and $P$. notatum var. notatum (an apomictic tetraploid), and that all other observed forms should be classified as biotypes (Canto-Dorow et al., 1996).

The diversity of the forms found in this study is much greater than what has been described for the species so far. Our results indicate that there is variability for all morphological characters analyzed and in particular for the angle between the racemes, the insertion angle of the leaves, and the length of flowering stems (Table 2). We also found variation in the number of racemes. It should be stressed that this is one of the traits used to characterize the Notata group of the genus Paspalum (Chase, 1929). Variation in this trait has been found to be most common in P. notatum var. saurae (Canto-Dorow et al., 1996).

Table 3 - Relative contribution of characters to divergence obtained from the Singh method (Singh, 1981)

\begin{tabular}{lc}
\hline Variable & Value (\%) \\
\hline Length of sheath & 5.71 \\
Width of sheath & 20.09 \\
Length of leaves & 16.61 \\
Width of leaves & 2.78 \\
Insertion angle of leaves & 4.34 \\
Number of racemes & 4.35 \\
Length of racemes & 21.59 \\
Angle between the racemes & 5.83 \\
Length of flowering stems & 18.70 \\
\hline
\end{tabular}




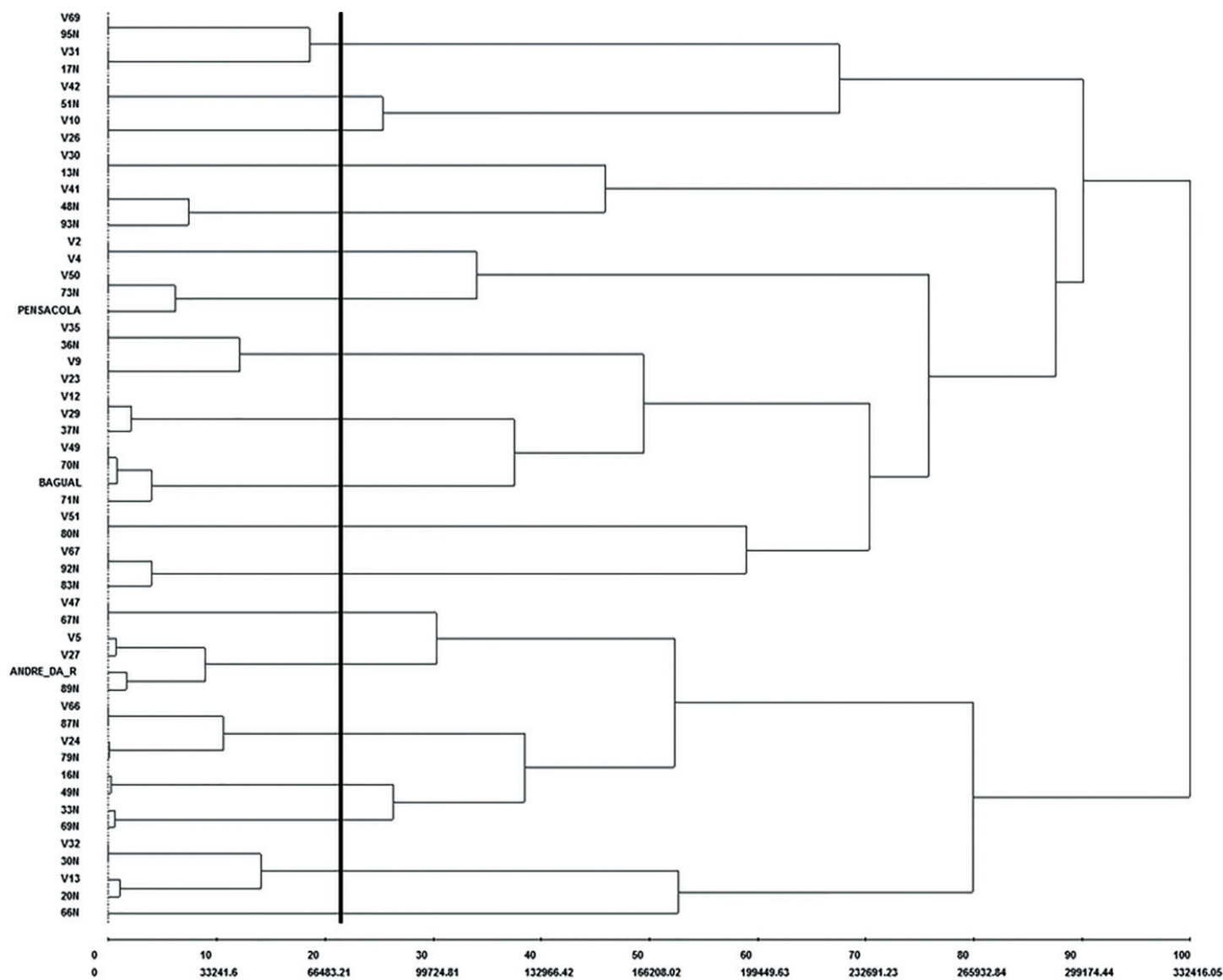

Figure 2 - Relationships among Paspalum notatum accessions based on quantitative traits obtained by Mahalanobis distance.

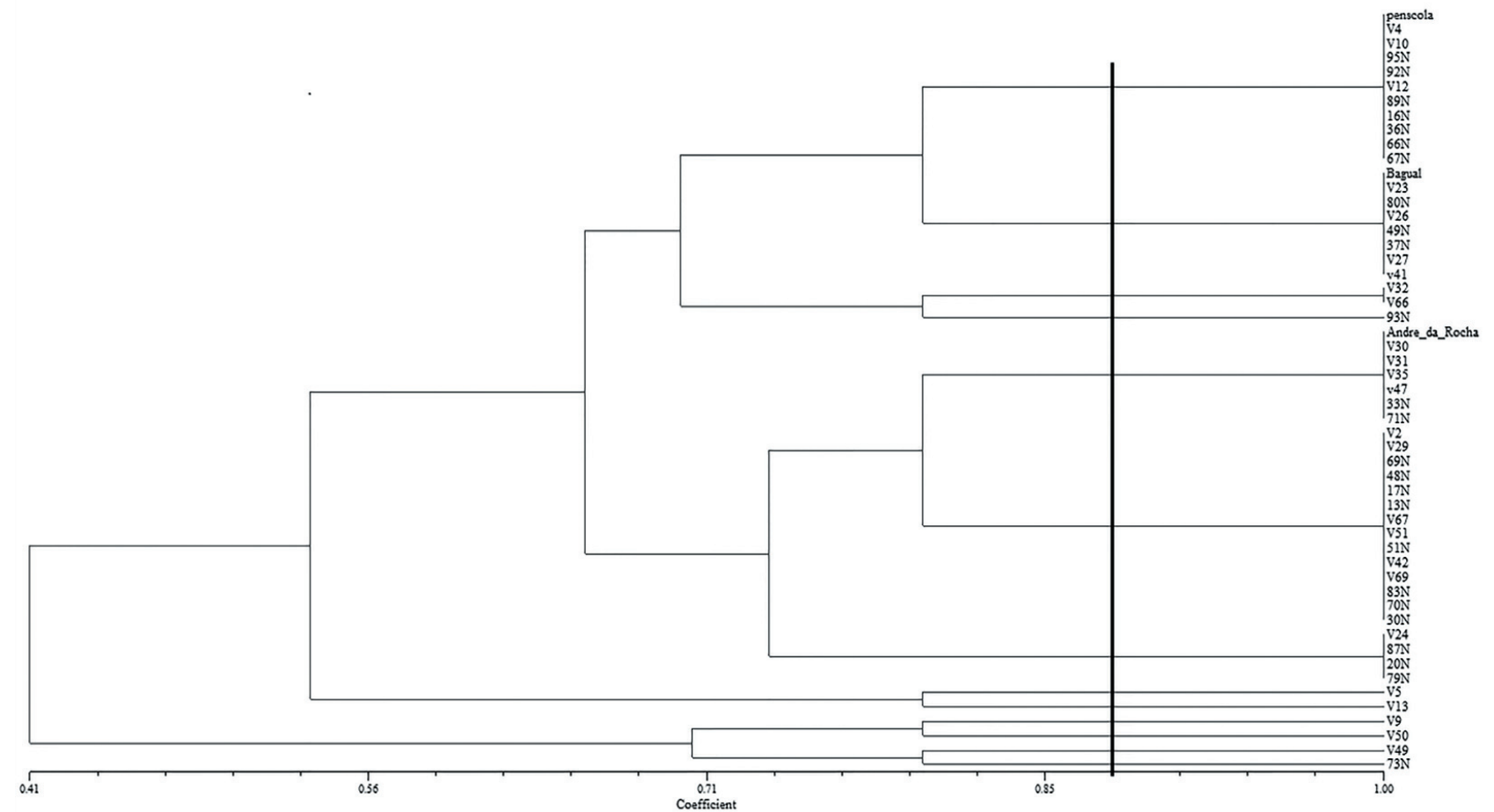

Figure 3 - Relationships among Paspalum notatum accessions based on qualitative traits obtained by Jaccard's similarity. 
The morphological groups found in this study showed varying degrees of correspondence to previously described classifications. Barreto (1974) described four "forms" of $P$. notatum based on aspect, vigor, size, and hairiness of the leaves; height of the stems; number and length of the racemes; and size and color of the spikelets. The relationship between those "forms" and the groups found in this study is not straightforward, since Barreto (1974) included only plants from the state of Rio Grande do Sul in his analysis, and the traits on which he based his classification were different from those used in our study.

Canto-Dorow et al. (1996) defined four biotypes of $P$. notatum based on the length and width of the leaves, presence or absence of hair, size of the spikelets, and number of veins in lemma I: biotype A leaf blades that are both long and wide; biotype $\mathrm{B}$, with long and narrow leaf blades; biotype $\mathrm{C}$, with short and narrow leaf blades; and biotype $\mathrm{D}$, which is characterized by pubescent leaf blades. Steiner (2005) classified 41 accessions into six morphological groups. The traits that most contributed to the formation of groups were length and width of the leaves, length of the racemes, and spikelets. Finally, Cidade (2006) performed a morphological characterization based on eight traits in 95 accessions of $P$. notatum, which resulted in the formation of eight groups. The traits that most contributed to the divergence among accessions in that study were height of the flowering stem, length and width of the leaf blades, and length of the racemes. The differences in the groups obtained in this study in relation to those reported by other authors are probably due to the use of larger number and different characters than those used in this study. In identifying 13 and 19 morphologic groups based on qualitative and quantitative data, respectively, in our morphological analysis of P. notatum, we report an intraspecific diversity that is greater than that found by any other authors. This is probably due to the inclusion of the older accessions obtained from the USDA, which resulted in greater geographical coverage and, hence, in a more comprehensive collection. Our results show that the recovery of material from germplasm seed banks can be an excellent strategy to increase the genetic variability in breeding programs. This increase is of particular importance for the success of breeding programs in apomictic species, such as $P$. notatum.

Apomixis is an alternative route of plant reproduction, in which parent plants produce genetically identical offspring via seeds. In agriculture, apomixis is desirable because it guarantees the perpetuation of superior genotypes by selfseeding without loss of hybrid vigor (Ortiz et al., 2013). In apomictic species, low diversity indices within each accession are expected (Dall'Agnol and Schifino-Wittmann, 2005). This low genetic diversity within accessions can be observed in an analysis of discrete morphological traits with two or three possible outcomes, such as color and pubescence of the sheath, color of the midrib, pubescence of the leaves, and plant habit. Most accessions showed no variation in these traits, allowing to restrict the analysis to a few individuals per accession. Moreover, the plants originating from UFRGS (coded as V) are clones, whose only source of variation is somaclonal, thereby, further reducing the possibility of variation within accessions (Rodrigues, 2008; Majesky et al., 2015). In the plant seeds obtained from the USDA (coded as N), on the other hand, some level of variation within accessions can be expected, since apomixis is facultative in most tetraploids of the genus Paspalum (Sartor et al., 2011), and a degree of genetic diversity is therefore possible in apomictic Paspalum species (Sartor et al., 2013; Majesky et al., 2015).

We have previously published an agronomic characterization and persistence analysis of these accessions, showing a high dry matter production (Fachinetto et al., 2012). Of the 52 accessions of $P$. notatum included in the study, 44 exceeded the forage production of the Pensacola cultivar, while showing persistence at the climatic conditions (winter) of the region where the experiment was conducted. The four accessions found to be most productive in our 2012 study (30N, 48N, 95N, and V4) were found in the present study to belong to different morphological groups (Figures 2 and 3).

When breeding facultative apomicts, the choice of genetically distant parents can help preserve the genetic variability and maximize heterosis, while the morphological characterization allows to select parents that combine desirable characteristics. In the accessions studied, those with bigger leaf blades and an erect habit have a higher dry matter production.

The groups identified in this study did not show a clear relation to the places of origin and accessions collected in the same or in nearby regions were spread over different groups. Conversely, the accessions in each group originated from a range of locations. This allows the selection of the morphological group with the most relevant features for the purposes of a breeding program, while at the same time maintaining the genetic variability of the material.

Those traits that contributed most to the variability among accessions are those that deserve most attention in the selection of materials for a breeding program. In special, the length of leaves, which contributes with $16.61 \%$ to formation of groups, is closely related to forage 
production and plant habit. The plant habit could thus be used to select accessions of a forage grass. An erect habit is an adaptation to the competition for light and erect plants tend to achieve a greater height (Bernardes, 1987). Plants with an erect habit can therefore be expected to have a greater forage production. In the case of $P$. notatum, the height is, in general, composed of the length of leaves and sheaths. However, plants with a prostrate habit may be better adapted to heavy grazing; they can therefore be used in continuous grazing systems and are better at colonizing new habitats (Zimmer, 1994).

In this context, it is of great relevance that the native region of $P$. notatum, the Pampa region, is under great threat of human urbanization and economic activities (Pillar et al., 2009). This greatly endangers the biodiversity of this biome, as well as the persistence of native species. The conservation of genetic diversity can be assisted by maintaining species populations in germplasm banks (Ferreira, 2006). The addition of this type of material to our study has increased the level of genetic diversity found above previously observed levels, thereby highlighting the importance of this type of conservation strategy.

\section{Conclusions}

There is a wide genetic variability among accessions of Paspalum notatum for morphological traits, which shows great relevance of this information in a program of genetic improvement of Paspalum notatum. The genetic similarity found among accessions can help the breeders to define the best parental for crosses, in which accessions of different clusters should be preferred.

\section{Acknowledgments}

The authors thank the Coordenação de Aperfeiçoamento de Pessoal de Nível Superior (CAPES), Conselho Nacional de Desenvolvimento Científico e Tecnológico (CNPq), and Fundação de Amparo à Pesquisa do Estado do Rio Grande do Sul (FAPERGS) for the financial support.

\section{References}

Adamowski, E. V.; Pagliarini, M. S.; Mendes-Bonato, A. B.; Batista, L. A. R. and Valls, J. F. M. 2005. Chromosome numbers and meiotic behavior of some Paspalum accessions. Genetic and Molecular Biology 28:773-780.

Azevedo, J. M. A.; Silva, H. S. F.; Assis, G. M. L.; Santos, L. F. A. and Wolter, P. F. 2011. Genetic divergence among accessions of Arachis repens based on vegetative morphological traits. Revista Brasileira de Zootecnia 40:2067-2073.
Barreto, I. L. 1974. O gênero Paspalum (Gramineae) no Rio Grande do Sul. Dissertação (M.Sc.). Universidade Federal do Rio Grande do Sul, Porto Alegre.

Bernardes, M. S. 1987. Fotossíntese no dossel das plantas cultivadas. p.13-45. In: Castro, P. R. C. Ecofisiologia da produção agrícola. Ed. Potafos, Piracicaba

Boldrini, I. I.; Ferreira, P. M. A.; Andrade, B. O.; Schneider, A. A.; Setubal, R. B.; Trevisan, R. and Freitas, E. M. 2010. Bioma Pampa: diversidade florística e fisionômica. Ed. Pallotti, Porto Alegre.

Borner, A.; Freytag, U. and Sperling, U. 2006. Analysis of wheat resistance data originating from screenings of Gatersleben genebank accessions during 1933 and 1992. Genetic Resources and Crop Evolution 53:453-465.

Canto-Dorow, T. S.; Longhi-Wagner H. M. and Valls, J. F. M. 1996. Revisão taxonômica das espécies de Paspalum L. grupo Notata (Poaceae - Paniceae) do Rio Grande do Sul, Brasil. Iheringia 47:3-44.

Chase, A. 1929. The North American species of Paspalum. Contributions from the United States National Herbarium 28:1-310.

Cidade, F. W. 2006. Análise da variabilidade genética de Paspalum notatum Flügge (Poaceae, Panicoideae) com o uso de marcadores moleculares, morfológicos e citometria de fluxo. Dissertação (M. Sc.). Universidade Federal do Rio Grande do Sul, Porto Alegre.

Cidade, F. W.; Dall'Agnol, M.; Bered, F. and Souza-Chies, T. T. 2008. Genetic diversity of the complex Paspalum notatum Flügge (Paniceae: Panicoideae). Genetics Resources and Crop Evolution $55: 235-246$

Cruz, C. D. 2006. Programa Genes: análise multivariada e simulação. Editora UFV, Viçosa, MG. 175p.

Dahmer, N.; Schifino-Wittmann, M. T.; Dall'Agnol, M. and Castro B. 2008. Cytogenetic data for Paspalum notatum Flügge accessions. Scientia Agrícola 65:381-388.

Dall'Agnol, M. and Schifino-Wittmann, M. T. 2005. Apomixia, genética e melhoramento de plantas. Revista Brasileira de Agrociência 11:127-133.

Fachinetto, J. M.; Schneider, R.; Hubber, K. G. C. and Dall'Agnol, M. 2012. Avaliação agronômica e análise da persistência em uma coleção de acessos de Paspalum notatum Flügge (Poaceae). Revista Brasileira de Ciências Agrárias 7:189-195.

Ferreira, M. E. 2006. Molecular analysis of gene bank for sustainable conservation and increased use of crop genetic resources. p.121127. In: The role of biotechnology in exploring and protecting agricultural genetic resources. Ruane, J. and Sonnino, A. eds. Fao, Roma.

Govindaraj, M.; Vetriventhan, M. and Srinivasan, M. 2015. Importance of genetic diversity assessment in crop plants and its recent advances: An overview of its analytical perspectives. Genetics Research International 2015:1-14.

Huber, K. G. C.; Dall'Agnol, M.; Motta, E. A. M.; Pereira, E. A.; Ávila, M. R.; Perera, M. Z. and Santos, T. N. 2016. Variabilidade agronômica e seleção de progênies F1 de Paspalum. Agrária $11: 374-380$

Machado, J. M.; Dall'Agnol, M.; Motta, E. A. M.; Pereira, E. A.; Simioni, C.; Weiler, R. L.; Zuñeda, M. P. and Ferreira, P. B. 2017. Agronomic evaluation of Paspalum notatum Flügge under the influence of photoperiod. Revista Brasileira de Zootecnia 46:8-12.

Majesky, L.; Vasut, R. J. and Kitner, M. 2015. Genotypic diversity of apomictic microspecies of the Taraxacum scanicum group (Taraxacum sect. Erythrosperma). Plant Systematics and Evolution 301:2105-2124.

Martuscello, J. A.; Braz, T. G. S.; Jank, L.; Cunha, D. N. F. V. and Fonseca, D. M. 2012. Genetic diversity based on morphological data in Panicum maximum hybrids. Revista Brasileira de Zootecnia 41:1975-1982. 
.Ortiz, J. P. A.; Quarin, C. L.; Pessino, S. C.; Acunã, C.; Martínez, E. J.; Espinoza, F.; Hojsgaard, D. H; Sartor, M. E.; Cáceres, M. E. and Pupilli, F. 2013. Harnessing apomictic reproduction in grasses: what we have learned from Paspalum. Annals of Botany 112:767-787.

Parodi, L. R. 1948. Gramíneas Argentinas nuevas o críticas. I. La Variación en Paspalum notatum Flügge. Revista Argentina de Agronomia 15:53-57.

Pereira, E. A.; Barros, T.; Volkmann, G. K.; Battisti, G. K.; Silva, J. A. G.; Simioni, C. and Dall'Agnol, M. 2012. Variabilidade genética de caracteres forrageiros em Paspalum. Pesquisa Agropecuária Brasileira 47:1533-1540.

Pereira, E. A.; Dall'Agnol, M.; Schneider, R.; Weiler, R. L.; Kuhn, N. J. I. S; Simioni, C.; Mazurkievicz, G. and Silva, J. A. G. 2015. Adaptabilidade e estabilidade em genótipos apomíticos do gênero Paspalum. Ciência Rural 45:1361-1367.

Pillar, V. P.; Müller, S. C.; Castilhos, Z. M. S. and Jacques, A. V. A. 2009. Campos Sulinos, conservação e uso sustentável da biodiversidade. MMA, Brasília.

Pozzobon, M. T. and Valls, J. F. M. 1997. Chromosome number in germoplasm accessions of Paspalum notatum (Gramineae). Brazilian Journal of Genetics 20:29-34.

Rodrigues, P. H. V. 2008. Somaclonal Variation in Micropropagated Heliconia bihai cv. Lobster Claw I Plantlets (Heliconiaceae). Scientia Agricola 65:681-684.

Rohlf, F. J. 1998. NTSYSpc Numerical Taxonomy and Multivariate Analysis System Version 2.0 User guide. Applied Biostatistics Inc., Setauket, New York. 37p.

Rosengurt, B.; Maffei, B. A. and Artucio, P. I. 1970. Gramíneas uruguayas. Universidad Publicaciones, Montevideo.
Santos, C. A. F.; Corrêa, L. C. and Costa, S. R. 2011. Genetic divergence among Psidium accessions based on biochemical and agronomic variables. Crop Breeding and Applied Biotechnology 11:149-156.

Sartor, M. E.; Quarin, C. L. and Espinoza, F. 2009. Mode of reproduction of colchicine-induced Paspalum plicatulum tetraploids. Crop Science 49:1270-1276.

Sartor, M. E.; Quarin, C. L.; Urbani, M. H. and Espinoza, F. 2011. Ploidy levels and reproductive behaviour in natural populations of five Paspalum species. Plant Systematics and Evolution 293:31-41.

Sartor, M. E.; Rebozzio, R. N.; Quarin, C. L. and Espinoza, F. 2013. Patterns of genetic diversity in natural populations of Paspalum agamic complexes. Plant Systematics and Evolution 299:1295-1306.

Singh, D. 1981. The relative importance of characters affecting genetic divergence. The Indian Journal of Genetics and Plant Breeding 41:237-245.

Steiner, M. G. 2005. Caracterização agronômica, molecular e morfológica de acessos de Paspalum notatum Flügge e Paspalum guenoarum Arech. Dissertação (M.Sc.). Universidade Federal do Rio Grande do Sul, Porto Alegre.

Streck, E. V.; Kämpf, N.; Dalmolin, R. S. D.; Klampt, E.; Nascimento, P. C. and Schineider, P. 2002. Solos do Rio Grande do Sul. Porto Alegre, Universidade Federal do Rio Grande do Sul. 107p.

Whitton, J.; Sears, C. J.; Baack, E. J. and Ottoy, S. P. 2008. The Dynamic nature of apomixis in the angiosperms. International Journal of Plant Science 169:169-182.

Zimmer, A. H.; Macedo, M. C. M.; Barcellos, A. O. and Kichel, A. N. 1994. Estabelecimento e recuperação de pastagens de Brachiaria spp. In: Anais do $11^{\circ}$ Simpósio sobre Manejo da Pastagem, Piracicaba. 